\title{
A REPRESENTAÇÃO DO PODER FEMININO NO ROMANCE RAINHA GINGA, DE AGUALUSA
}

\author{
Maria do Desterro da Silva Oliveira (UESPI) \\ Algemira de Macêdo Mendes (UESPI)
}

Resumo: Este trabalho tem por objetivo abordar o tema literatura angolana, gênero e relações de poder. Selecionou-se o romance Rainha Ginga, de José Eduardo Agualusa, publicado em 2015. O recorte trilhado dessa narrativa visa demonstrar como se deu a ascensão de Ginga ao trono dos reinos Ndongo, Matamba e Angola. A biografia da rainha de Angola registra desavenças familiares com o irmão, Kia Ngola Mbandi. $\mathrm{O}$ conflito entre os irmãos talvez fosse oriundo do afeto demasiado de Ngola Kiluanji para com a filha, por ela demonstrar suas habilidades bélicas e sua liderança nata. Essas características representavam uma ameaça ao herdeiro do trono. Após a morte do Ngola Kiluanje e Kia Ngola, a princesa Ginga tornou-se a primeira na linha de sucessão do trono real. No entanto, ela teve que lidar com a desconfiança do povo Ambundu, pois não aceitavam serem liderados por uma mulher. A pesquisa realizada tomou como fonte as informações históricas e literárias, a partir das contribuições teóricas de Fonseca (2010), Souindoula (2014), Leite (2012), Caley (2014), Mata (2003), Malumbo (2014), Kwononoka (2014), Pantoja (2014) Pinto (2015), entre outros, cujas teorias corroboraram os objetivos propostos. Com base nos teóricos mencionados, notou-se que os discursos expõem a trajetória política e diplomática dessa mulher. Ela tornou-se símbolo da resistência africana diante dos conquistadores europeus, especialmente dos portugueses.

Palavras-chave: Literatura Angolana; Gênero; Rainha Ginga; Poder Feminino

Abstract: The representation of female power in the novel $A$ Rainha Ginga, by Agualusa This paper aims to address the theme of Angolan literature, gender and power relations. In order to build this work, the novel Rainha Ginga by José Eduardo Agualusa, a book published in 2015, was selected. The part of the narrative discussed here is aimed at showing how Ginga rose to the throne of the Ndongo, Matamba and Angola kingdoms. The biography of the queen of Angola registers family quarrels with her brother, Kia Ngola Mbandi. The conflict between the 
siblings might have come from Ngola Kiluanji's too much affection for his daughter, for she had demonstrated her warlike abilities and natural leadership. These characteristics represented a threat to the heir to the succession of the throne. After the death of Ngola Kiluanje and Kia Ngola, Princess Ginga became the first in the line of succession of the royal throne. However, she had to deal with the distrust of the Ambundu people, as they did not accept being led by a woman. This research took as source the historical and literary information, from the theoretical contributions of Fonseca (2010), Souindoula (2014), Caley (2014), Mata (2003), Malumbo (2014), Kwononoka (2014), Pantoja 2014) Pinto (2015), among others, whose theories corroborated with the proposed objectives. Based on the mentioned theorists, it was noticed that the speeches expose the political and diplomatic trajectory of this woman. She has become a symbol of African resistance to European conquerors, especially the Portuguese.

Keywords: Angolan Literature; Gender; Queen Ginga; Female power.

O objetivo dessa pesquisa é o de retratar episódios relevantes da história de Angola pelo viés da narrativa literária. As invasões europeias a partir do século XV e a chegada dos primeiros portugueses no território de África tornaramse preponderantes para o mote narrativo. $O$ romance $A$ Rainha Ginga e de Como os Africanos Inventaram o Mundo destaca a trajetória política, militarista e diplomática dela. Historicamente, a presença da embarcação de Diogo Cão, no rio Zaire, marca o início da entrada portuguesa em África. Conforme menciona Sousa (2003, p.72) “Em 1482-3, a mando do reino português, Diogo Cão aportou na foz do rio Zaire, chegando pela primeira vez no atual território angolano". O pioneirismo de Diogo Cão estimulou a exploração portuguesa 
das terras africanas nos séculos posteriores. E no século XVI a África tornou-se um negócio rentável. Esse fator despertou o interesse de outros países europeus. Com isso, os territórios africanos transformaram-se em rota "comercial" de muitos países europeus, especialmente Holanda e Portugal.

Ressalta-se que, a princípio, as relações comerciais entre portugueses e angolanos eram amistosas. No entanto, os portugueses passaram a violar os acordos com os africanos e com isso, iniciou-se o tráfico de pessoas e a expropriação de terras dos autóctones. Assim, a história de Angola nos séculos XVI e XVII foi marcada por um acentuado processo de invasões estrangeiras, principalmente dos povos portugueses, holandeses e alguns espanhóis. Além da presença estrangeira, havia conflitos internos devido aos interesses das diversas etnias e de alguns reinos.

As divergências internas entre os reinos do referido território africano foram preponderantes para a expansão imperial europeia, fortalecendo principalmente os povos lusos. E nesse contexto histórico os holandeses ameaçavam a expansão imperialista dos portugueses em Angola. A população autóctone vivia constantes ameaças de invasões europeias, guerras internas e exploração. O mosaico étnico no território de Angola facilitou a atuação dos portugueses 
e devido às inúmeras disputas entre grupos rivais muitas pessoas eram capturadas e vendidas para serem escravas nas colônias portuguesas.

O rapto de pessoas tornou-se uma prática recorrente e violenta. Os autóctones capturados embarcavam para os territórios da América Espanhola e outros eram enviados para o Brasil. No entanto, os portugueses perceberam que poderiam ter mais lucros. E com essa concepção mercantilista passaram a traficar escravos. Isso desagradou alguns reis angolanos no período setecentista. Por outro lado, muitos angolanos aliaram-se aos portugueses. Esta aliança desencadeou a chamada "Guerra Preta", na qual africanos lutavam ao lado dos portugueses. O pacto bélico entre alguns angolanos e portugueses é ressaltado pela pesquisa histórica de Mariana Fonseca.

Ao lado dos generais portugueses, lutavam africanos designados por seus sobas em sinal de obediência. As guerras em Angola não existiriam sem a maciça participação dos africanos, que atuavam como soldados, carregadores, guias na densa mata, coletores de alimentos, já que a fome era um grande problema dos exércitos em Angola. Além do braço para a guerra, os africanos combatentes utilizavam seus conhecimentos tribais na preparação para a luta, as estratégias bélicas próprias para aquela geografia e 
suas próprias armas (machadinhas, arcabuzes, lanças). O uso de armas de fogo foi pouco empregado neste primeiro momento da "conquista". Assim, as guerras angolanas foram essencialmente guerras vividas por africanos dos dois lados (FONSECA, 2010, p.392-393).

Conforme Fonseca (2010) os portugueses, em suas empreitadas bélicas e expansionistas contavam com a participação dos africanos, sobretudo, aqueles que tinham como rivais os próprios conterrâneos. No entanto, aliar-se aos portugueses não era prática da maioria dos africanos. O Ngola Kiluanji, pai de Ginga Mbandi, resistia aos avanços lusitanos, procurava aliados a fim de manter o território, diminuir a usurpação dos recursos naturais e evitar o comércio de escravos. No cenário de guerras internas e alianças, Ngola Kiluanji contava com o auxílio dos sobas e dos reinos descontentes com a "política" portuguesa. Pinto (2015) registra historicamente algumas alianças de Ngola Kiluanji:

A derrota portuguesa em AngolemeAkitambo ficou a dever-se ao fato de o Nzinga Ngola Kilombo Kia Kasenda (ou o Mbandi-a-Ngola Kiluanji) se ter coligado com dois outros soberanos angolanos. Eram eles o Ntotila do Kongo, D. Álvaro II Mpangu-a-Nimi Lukeni Lua Mvemba, que reinava desde 1587 e... o rei da Matamba um "Jaga"! (PINTO, 2015, p.279). 
Os portugueses possuíam um exército bem treinado para batalhas e tinham a colaboração de alguns chefes de tribos africanas. Para vencer tal poderio, os soberanos angolanos usavam a estratégia de unir-se contra um inimigo comum. $\mathrm{O}$ pacto entre angolanos tornou-se fundamental para vencer muitas batalhas travadas contra o colonizador europeu. Além dos soberanos mencionados por Pinto (2015), Ngola Kiluanji tinha o apoio de uma mulher, sua própria filha, a princesa Ginga. Esta não temia os rivais europeus, enfrentava-os em nome do patriotismo e do espírito aguerrido.

Selma Pantoja (2014, p.115) acrescenta que: “As narrativas de tradição oral do povo mbundu descrevem a rainha Nzinga Mbandi como temida pelos seus súditos e inimigos, e foi vencedora das batalhas mais estupendas contra os europeus". Pantoja ressalta a ideologia que o povo africano e português do século XVII tinha acerca da soberana do Ndongo. No imaginário dos contemporâneos da nobreza, a figura de Ginga remete a uma mulher altiva, que desperta o respeito e o temor até mesmo dos inimigos. Conforme os discursos históricos, ela tinha habilidades bélicas raramente contestadas, por isso em muitas batalhas ela liderava exércitos. Ginga fazia pactos e selava acordos com os quais pudesse sobrepor o poderio dos portugueses. Kwononoka 
(2014) elenca as principais batalhas que ela liderou, bem como o nome dos aliados dela.

Batalha de Ngolomen-a-Kaita (nome de um soberano aliado da rainha;

Batalha de Senga a Kavangaen, 1946. A rainha enfrentou $20 \mathrm{mil}$ soldados portugueses, do Ngola Ari de Kabuko já Ndonga e emcapasseiros (soldados africanos com armas de fogo). A rainha aliou-se com os sobas Ifamuto e Kakulo Kayenda. A rainha foi derrotada; Batalha de Lumbo em terra de Kakulo Kahoji. A rainha contou com o apoio do Ntotila Nkanga a Lukeni, os portugueses foram derrotados; Batalha de llamba a 1 de agosto de 1648 contra o exército de Luanda. Morreram todos os oficiais portugueses, o capitão-mor Filipe Ngola Ari, filho Fo Ngola, rei do Ndongo;

Batalha de Wandu, onde os portugueses foram igualmente esmagados (KWONONOKA, 2014, p.2014)

Segundo o fragmento de Kwononoka, Ginga participou de várias batalhas e saiu vitoriosa na maioria delas. Ao longo do romance em análise, o narrador descreve-a como uma mulher astuta, capaz de enfrentar os reveses bélicos e isso garante a ela uma posição de destaque na política militarista, de enfrentamento às invasões portuguesas. Tal comportamento demonstra que a princesa ocupava funções políticas e bélicas consideradas tipicamente masculinas. 
O comportamento combatente de Ginga justifica-se pelo treinamento militar que ela possuía. O rei do Ndongo, Ngola Kiluanji, pai da heroína do romance de Agualusa e da história de Angola, oportunizou a criação de ambientes nos quais a filha mais velha pudesse receber a educação guerreira e diplomática,

O rei, seu pai, mandou-a educar com grande cuidado e de acordo com o seu estatuto e, como a amava muito mais do que a todos os outros filhos, porque reconhecia uma extraordinária vivacidade de espírito e uma sagacidade, abençoava-a muitas vezes aquando das cerimônias da seita, em que punha um cuidado especial ao ensinar-lhe os dogmas para que ela impregnasse deles com todo o coração e se ligasse a ele (CAVAZZI, 2013, p.59).

A heroína da história de Angola e do romance de Agualusa era diferente das demais mulheres angolanas, principalmente das poucas mulheres europeias que viviam em território angolano no século XVII, as quais são mencionadas no romance. Em muitos territórios de África as sociedades eram matrilineares, mas elas não exerciam o pleno poder gestor, visto que as funções mais "respeitáveis" eram destinadas ao homem. Kabengelê Munanga (1996, p.61) acrescenta que:

A maioria dos povos da África central pratica o sistema de parentesco 
matrilinear, em relação à descendência, estrato social, sucessão e herança. Embora a descendência e as linhagens constituídas fossem matrilineares, a autoridade ficava sempre nas mãos dos homens e não das mulheres.

As premissas de Munanga sobre o papel da mulher em África Central demonstram que mesmo nas sociedades onde as mulheres tinham maior participação, as atividades mais significativas ainda eram destinadas aos homens. Entretanto, o romance $A$ Rainha Ginga narra uma mulher de forte liderança, com poder governamental, diplomático e de enfrentamento. Ao contrário do que se relata no romance de Agualusa, Kwononoka (2014, p.60) enfatiza que:

$\mathrm{Na}$ África bantu não era comum uma mulher, em sociedades tipicamente machistas, embora matrilineares e gerontocráticas, uma mulher com intrepidez, sagacidade, capacidade diplomática e sem preconceitos feministas, dirigir um Estado, papel reservado tradicionalmente aos homens e aos mais velhos, ligados ao sangue, valor ou descendência real.

Kwononoka (2014) e Munanga (1996) ambos enfatizam que o papel feminino em algumas sociedades Áfricas era limitado em detrimento do poder masculino. A eles destinavam atividades políticas, bélicas e diplomáticas. Para 
as mulheres, mesmo em sociedades matrilineares, o poder feminino estava reservado ao espaço privado. No entanto, em Angola, Ginga Mbandi teve grande representatividade política. O âmbito privado ainda permanece como o espaço onde muitas mulheres exercem essa relação de poder desigual e binária (homem espaço público X mulher espaço doméstico). A respeito das discussões sobre o espaço feminino na sociedade a pesquisadora Carla Martins (2005) afirma que:

O domínio privado é, essencialmente, não político ou pré-político, e abre-se a uma dupla leitura: por um lado, numa acepção positiva, privado surge como "refúgio" e lugar onde o indivíduo se protege da constante exposição pública... No domínio do lar - habitado pelas mulheres, escravos, servos - imperava a desigualdade e representava a antítese da liberdade e igualdade, os traços caracterizadores da existência público política... que tudo o que vem a público pode ser visto ouvido por outros e tem a maior divulgação [publicity] possível (MARTINS, 2005, p.705).

As acepções de Carla Martins sobre o lugar da mulher na sociedade demonstram que o espaço delegado às mulheres é um território de invisibilidade discursiva. Esses não oportunizam condições de diálogos. Tal fato torna 
as relações de poder entre homem e mulher um discurso unilateral. Nesse caso, apenas o sujeito masculino tem poder quando se refere à tomada de decisões no âmbito público. Em contraste ao discurso sociológico de Martins, a história de Ginga Mbandi e Cleópatra são exemplos de poder feminino em África.

As rainhas de Angola e do Egito, respectivamente, podem representar a minoria de mulheres que exerciam o poder além do espaço doméstico. Ginga e Cleópatra, por serem destemidas e altivas, comandavam e defendiam seus territórios. A pesquisadora em literatura e gênero, Maria Aparecida de Oliveira Silva, ressalta a liderança da rainha egípcia:

Cleópatra desempenhou um importante papel na história do Mundo Antigo. Ao tornar-se rainha, aos dezoito anos, idealizou reconstruir o Império de sua casa dinástica por meio de uma política de valorização do Egito. Para realizar tais aspirações, além de suas habilidades na política interna egípcia, utilizou-se de seus relacionamentos com os generais Júlio César e Marco Antônio, a fim de garantir o apoio da maior potência da época - Roma. Assim sendo, sua participação nas guerras civis latinas é um dos fatores que marcam a derrocada da República e o ínicio do Imperio romano, o que a tornou uma das poucas mulheres que excerceram o poder nos eventos políticos de sua época (SILVA, 2010, p.1) 
Cleópatra exercia poder sobre os imperadores do Egito, ao passo que a princesa Ginga Mbandi se mostrava sagaz nas artes da guerra desde a juventude. A nobre de Angola também pôs sua liderança para além do ambiente privado. Sendo esta, fundamental nas guerras contra Portugal. Por ser destemida e impetuosa muitos a comparavam a Cleópatra. Cleópatra exercia também atividades políticas e tinha grande influência no Egito. Com atitudes semelhantes às da rainha do Egito, a princesa Ginga Mbandi mostrava-se sagaz nas artes da guerra. Nesse sentido, Pinto (2015, p.301) acrescenta que: "O facto de Njinga Mbandi se tratar de uma mulher não é alheio a seu prestígio e já houve mesmo quem Ihe chamasse de Cleópatra angolana".

A nobre do Ndongo e da Matamba não se submetia aos desígnios de nenhum homem, tampouco dos europeus. O interesse dela pela guerrilha foi estimulado pelo pai, mesmo contrariando os paradigmas de uma sociedade com características patriarcalistas. E as sociedades com aspectos do patriarcalismo suprimem os poderes e os espaços femininos. Além disso, impõe regras e limites de poder destinado às mulheres. Sadiqi (2008, p.12) explica que: "o sistema patriarcal é constituído sobre a exclusão das mulheres dos espaços de poder público e pela sanção de 
todas as formas de violência física e moral contra elas nestes espaços". Ginga rompeu com os paradigmas da sociedade do Ndongo, pois ela manteve-se à frente das discussões políticas e bélicas. E com base nas discussões do historiador angolano Souindoula (2014) é possível afirmar que:

A singular estampilhagem da forte personalidade da futura heroína começa, desde a tenra idade, com o seu posicionamento parental visivelmente patrilinear. Parece estar sob o cuidado do pai, que é natural e duplamente Ngola e Kiluanji, quer dizer, líder político e chefe do exército. A jovem de forte corpulência física foi manifestamente marcada por uma educação patriótica e a adopção de uma conduta estritamente marcial (SOUINDOULA, 2014, p.103).

A princesa do Ndongo mostrava-se forte e preparada para assumir as funções de uma estadista. A confiança paternal do rei em sua filha mais velha provocava a insegurança em Ngola Mbandi, herdeiro potencial do trono. O irmão de Ginga, que era o primeiro na linha de sucessão, sentia-se ameaçado pela relação tão devotada entre a irmã e o pai. E após a morte do Ngola Kiluanji, o ritual de sucessão do trono cumpriu-se conforme os ritos da sociedade Ndongo, Ngola Mbandi é nomeado rei. Quando o irmão de Ginga assumiu o trono real, após a morte do pai, Ngola Kiluanji, 
provocou atrocidades contra as próprias irmãs, dentre estas, tornando-as estéreis.

Diante de tamanha violência, a princesa, heroína de Angola, teve que suportar e resistir à discórdia familiar, a fim de combater contra as forças portuguesas. Pinto (2015) enfatiza as práticas violentas de Ngola Mbandi para com sua família. Além de relatar a imprudência que levou a primeira derrota do soberano do Ndongo ao atacar o exército português:

I) Mata o filho de Njinga Mbandi, ainda criança;

II) Torna estéreis as três irmãs, Njinga, Nfungi, Nkambu, mutilando-lhes os úteros com água fervente e ferros em brasa;

III) Finalmente, declara guerra aos portugueses.

Essas notas de Cavazzi desfavoráveis ao Ngola Mbandi acresce ainda uma outra de Cadornega, segundo o qual o jovem soberano do Ndongo, uma vez entronizado, também pôs fim à vida de um seu igualmente criança, tal como o sobrinho, e que alegadamente, seria herdeiro legítimo do trono. (PINTO, 2015, p.316)

Nota-se que Ginga precisou superar os atos de violência praticados pelo próprio irmão e diante do conflito familiar e de invasões estrangeiras, revelou-se ponderada. Ela agia 
de forma estratégica e ao mesmo tempo combativa. Por outro lado, as irmãs, Mocambo e Quifungi, não tinham tanta habilidade nas batalhas bélicas, mas mesmo assim, no cenário de guerras e conquistas, as irmãs de Ginga exerciam também funções as quais pudessem auxiliá-la.

Raramente, as irmãs mais novas da soberana são mencionadas na narrativa, embora sejam fundamentais no desenvolvimento do enredo. Uma das principais menções feitas a elas é quando o narrador relata a captura de Quifungi e Mocambo, durante um ataque português contra os Mbundis. Kwononoka (2014) evidencia que as princesas Mocambo e Quifungi foram raptadas na Batalha de Senga a Kavangaem em 1646. Esse fato ocorreu, quando a rainha do Ndongo e Matamba guerreava contra os portugueses, do Ngola Hari. Literariamente, Agualusa (2015) expõe que as princesas foram capturadas durante uma das "guerras pretas". Isso porque durante uma batalha empreitada pela família Mbandi as duas princesas foram capturadas pelos portugueses. O relato do padre Francisco da Cruz evidencia como ocorreu esse ataque, no qual culminou com a prisão das nobres Mbandis.

O português, um dos poucos que viajava a cavalo, indo e vindo entre a cabeça da tropa e a sua retaguarda, dando instruções e trocando notícias, disse- 
me que toda aquela gente, ou quase toda, fora capturada pela guerra preta. Entre os cativos contavam-se as duas irmãs da Ginga, a doce Mocambo e a valente Quifungi. Vendo a minha aflição aproximou-se da liteira onde eu seguia e acrescentou que também Muxima caíra nas mãos dos nossos perseguidores. Ela e as duas esposas mais velhas de Domingos Vaz, e os filhos delas. Quis saber o que iria acontecer-lhes. Cipriano pareceu condoer-se de mim. Disse-me que seriam levados para Luanda e repartidos pelos senhores de escravos. Mocambo, Quifungi e outras senhoras de sangue real receberiam, com toda a certeza, um tratamento ajustado à sua elevada posição. O governador iria querer mantêlas de boa saúde, como exemplo da benevolência dos portugueses, e porque poderiam ser-lhe úteis para negociar a paz com a rainha Ginga. (AGUALUSA, 2015, p.37-38).

No fragmento mencionado, o padre Francisco da Cruz, expõe um dos momentos das invasões portuguesas ao reino Ndongo. Na batalha narrada, os conquistadores surpreendem os guerreiros de Ginga e capturam as irmãs dela. Nota-se que as princesas foram surpreendidas e devido a esse fator elas não demonstraram resistência à captura. Por outro lado, para os portugueses a prisão de Mocambo e Quifungi seria um valioso estratagema, uma vez que poderiam exigir dos líderes do Ndongo mais territórios, escravos, entre outros 
recursos, e em troca devolveriam as nobres. A narrativa romanesca de Agualusa evidencia o momento do regaste de Mocambo e Quifungi, assim como é relatado pelo padre Francisco da Cruz no trecho a seguir:

Distingui o rosto furtivo de Mocambo, meio oculto atrás de uma pilha de tecidos, e no mesmo instante compreendi tudo. Aproximei-me para cumprimentar. Mocambo distinguia-se pelo porte altivo, a graça com que se comovia e uma doçura que a todos conquistava. Quifungi era o oposto dela, de feições rudes e natureza antipática. Possuía, porém, a mesma grande coragem e lucidez da rainha, Mocambo mostrava-se assustada, ansiosa por sair de Luanda. Quifungi, ao contrário, estava muito calma - mas não queria ir. - Devo ficar, posso ser útil à minha irmã permanecendo em Luanda (AGUALUSA, 2015, p.101).

Mesmo com a tensão de Mocambo, observa-se que as princesas demonstraram muita astúcia e coragem, uma para fugir de Luanda e a outra para permanecer. O objetivo de Quifungi era torna-se uma espécie de informante para os governantes do Ndongo. O trecho acima narra o momento em que o padre chega a Luanda, com o cigano Cipriano. No entanto, o clérigo não sabia dos planos de Ginga e Cipriano, isso ele percebe somente ao encontrar as princesas Mocambo e Quifungi. A líder do Ndongo tinha dois planos 
para resgatar as irmãs. Uma das táticas era o resgate furtivo das princesas, mantidas sob o jugo português. A outra estratégia era entregar o sacerdote, ao governo luso, pois esse era odiado pela coroa e pela igreja católica. Ainda com base no fragmento citado, nota-se que Quifungi tinha planos para ajudar a princesa Ginga, contra os portugueses.

O romance histórico de Agualusa sobre Ginga Mbandi mostra a habilidade e inteligência da líder do Ndongo. O relato de Cavazzi evidencia que o retorno de Mocambu e Quifungi foram oriundos de negociações entre o Ngola, Ginga e o governador luso. De acordo com Cavazzi (2013, p.62), “As três princesas foram devolvidas à liberdade. Estavam muito contentes com as honrarias e bons tratamentos que haviam recebido em Luanda". Elas receberam um tratamento benevolente do governador português em Luanda. Possivelmente, para manter a integridade total delas a fim de barganhar com o líder angolano o que fosse de importante para a coroa a portuguesa.

A irmã mais velha exercia forte influência sobre as princesas Mocambo e Quifungi, por isso elas participavam desse projeto de reconquista. Nesse sentido, elas participavam junto ao exército da líder do Ndongo. Tal comportamento acontecia porque se sentiam encorajadas por tamanha 
representatividade de Ginga Mbandi. Nessa perspectiva, Kwononoka (2014, p.64) expõe que: “A liderança da mulher guerreira contagiou o espírito da sua irmã Kambu para dirigir tropas, ao ponto de ser capturada em pleno combate na batalha de Sena a Kavanga em 1646". Nota-se que, apesar do exemplo de força e resiliência da princesa Ginga, as irmãs dela, Kambu e Mocambo não eram hábeis como a futura rainha do Ndongo e Matamba.

De acordo com Agualusa, no romance Rainha Ginga (e de como os Africanos inventaram o mundo) (2015) Quifungi e Mocambo tinham personalidades diferentes, Mocambo (Kambu) era mais tranquila, doce, ao passo que Quifungi possuía uma personalidade forte e brava. O aprisionamento delas tinha como objetivo forçar a rendição dos soberanos do Ndongo. Esse fato tornou-se fundamental para que Ginga garantisse o status de diplomata do Ndongo. Dessa forma, ela pôde garantir mais poder e respeito diante dos sobas da sociedade ndonga e do governo português em Luanda:

Jinga foi indicada para ser embaixadora do rei do Ndongo pelo seu irmão Ngola Mbandi junto dos portugueses em 1660... Njinga Bandi começa, então, a desempenhar o papel de verdadeira soberana do Ndongo junto dos portugueses. Primeiro porque não deixa sinais de que o reino Ndongo que 
representava estivesse enfraquecido. Segundo, nessa altura, o reino de Kassanje já tinha sido, diríamos, submetido e, algumas vezes terá dado sinais de colaborar com o invasor (CALEY, 2014, p.73).

Ser nomeada embaixadora, representante do reino Ndongo, possivelmente, foi o início de acordos favoráveis ao Ngola Mbandi. Nesse sentido, os textos históricos e relatos de Cavazzi afirmam que ele organiza duas embaixadas para realizar negociações com o governador português. Ainda nessa perspectiva, Cavazzi (2013) relata que o Ngola Mbandi ordenou que a embaixada real fosse a Luanda para negociar com os portugueses a paz e a liberdade das irmãs e também da esposa, sequestradas pelo exército luso. A atuação diplomática da princesa Ginga tornou-se fundamental para selar um acordo de paz, mesmo que temporário. Consoante ao discurso narrativo de Agualusa, o rei do Ndongo solicitou que o conselheiro da irmã, o padre Francisco da Cruz escrevesse uma carta ao governador Luís Mendes Vasconcelos. Segundo Agualusa (2015, p.15):

Ngola Mandi sossegou. Ordenoume escrevesse uma carta redigida ao governador Luís Mendes Vasconcelos. Solicitava o rei que aquela poderosa autoridade recebesse em Luanda uma embaixada sua, à cabeça da qual 
iria a irmã mais velha, que tinha por conselheira preciosa.

Este fragmento corresponde ao relato do padre, secretário e conselheiro da princesa Ginga. Ela aceita a missão diplomática, apesar das desavenças e ultrajes fraternais. Habilidosa como era, Ginga percebeu o período turbulento e que havia um inimigo maior. Nesse sentido, durante as invasões estrangeiras não se admitia que ressentimentos pusessem o reino em perigo. As terras Ndongas encontravam-se ameaçadas pelo forte exército luso. Por isso, quando ela observava alguma fragilidade nos planos de Ngola Mbandi, a protagonista do romance de Agualusa discordava com veemência.

No momento que era oportuno à soberana e heroína do reino Ndongo e de Angola, mantinha-se como aliada do irmão. E ficava presente em todas as discussões, articulando planos sobre como derrotar os portugueses. Junto aos sobas do reino Ndongo, ela almejava expulsar os portugueses e recuperar seu território. A princesa Ginga tinha grande poder de argumentação. Além do mais, ela comportava-se como os guerreiros do Ndongo. Não se sujeitava, nem mesmo perante as normas do irmão, o rei Ngola Mbandi. Entretanto, muitas vezes, ela precisava auxiliar o irmão, Ngola Mbandi, conforme enfatiza Cavazzi (2013, p.63): 
A princesa que era cheia de espírito e dissimulação, fingiu esquecer o assassínio do filho, resolvida a prosseguir com a vingança logo que tivesse oportunidade. Disfarçando o seu rancor, que porém lhe remoia as entranhas, aceitou a missão e prometeu velar pelos interesses do irmão. Avisou-se o governador da sua chegada próxima, enquanto preparava o cortejo numeroso e magnífico que deveria acompanhá-la na sua embaixada. Njinga pôde finalmente acrescentar ao seu nome o título de ngambele ou portadora da palavra do rei.

No fragmento mencionado, Cavazzi descreve a princesa Ginga como um ser de personalidade fria, dissimulada e vingativa. Isso evidencia uma concepção pejorativa, que parte da visão daquele que apoia o sistema colonial. A reação de Ginga demonstrava a força e controle que ela detinha, mesmo em situações de conflitos. O modo racional e diplomático como ela agia, tornou-se fundamental nas negociações com os portugueses. Reconhecendo o poder estratégico de Ginga, Ngola Mandi recorre à irmã a fim de evitar retaliações por parte dos portugueses.

E de acordo com a narrativa de Agualusa (2015), após várias discussões com o irmão, a princesa Ginga parte rumo a Luanda. A ela foi destinada a missão de convencer o governador de interromper a construção do presídio de 
Ambaca e a captura de escravos. Kwononoka (2014) destaca os papéis sociais de Ginga para o reino do Ndongo.

Njinga Mbandi inicia a sua carreira política em 1622 como embaixadora de seu irmão do Ndongo em Luanda, a fim de negociar a paz e tentar conciliar os interesses do Ndongo com os portugueses, numa altura em que o Ndongo era palco de guerras sangrentas que Portugal the movia para submeter esse estado africano. De diplomata passou, a guerreira e sempre que a situação o exigisse, dirigia pessoalmente o seu exército nas frentes de combate (KWONONOKA, 2014, p.63).

A partir das concepções historiográficas de Kwononoka, a princesa não se isentava de nenhuma responsabilidade diplomática ou bélica. Com isso, ela exerceu várias funções desde embaixadora a militar nas frentes de guerras. A heroína de Angola impunha-se perante o irmão, discordava quando era necessário. Agualusa (2015) relata as divergências fraternais entre os Mbandis.

Ginga discutia em alta voz com o irmão, como ele partilhasse a mesma vigorosa condição de macho e de potentado. Já na altura não admitia ser tratada como fêmea. E era ali tão homem que, com efeito, ninguém a tomava por mulher (AGUALUSA, 2015, p.12-13). 
O fragmento citado reflete a concepção que o povo do Ndongo tinha de Ginga, pois muitos não concebiam o comportamento da soberana como natural. Os súditos de etnia ambundos pertenciam a uma sociedade patriarcal e não consentiam que uma mulher liderasse exércitos, tampouco fossem comandados por uma. O próprio narrador e secretário da princesa demonstra em seu relato um tom de estranhamento em relação ao fato de uma mulher direcionar e administrar um território. O fato de ela ser tão viril quanto um homem é outro ponto de vista do narrador, este evidencia que para ser respeitada como uma líder, ela precisava ter comportamentos imperativos típicos de homens. Dessa forma, o padre Francisco da Cruz sugere que a bravura é algo intrínseco ao homem (sexo masculino).

Para o narrador, uma mulher agir como um guerreiro é um feito inédito. Na época (século XVII), destinava-se a maioria das mulheres apenas o espaço doméstico, ou posições que não fossem de extrema responsabilidade. Ginga é um caso especial na história e na literatura de Angola. Assim muitos autores buscam nessa mulher fonte para recriar, via discurso literário, a história da escravidão e as lutas de resistência.

A nobre do Ndongo e da Matamba não media esforços para alcançar os objetivos, a retomada dos territórios africanos 
e acabar com a escravidão e o tráfico. E para isso, Ginga utilizava como estratégia a morte de alguns reis vizinhos do território de Matamba, os quais se resignassem diante dos portugueses. Por isso, ela também foi acusada de mandar decaptar o próprio tio, envenenar o irmão e apunhalar o filho de Ngola levando a morte deles. Dito dessa forma, parece que Ginga é uma mulher cruel, revanchista, no entanto, o legado que foi deixado por ela não pode ser esquecido. Pois diante dos conflitos bélicos entre os africanos e o povo luso, no centro do embate está presente a figura lendária da rainha Ginga.

Após a morte do irmão e sobrinho, ela mais uma vez teve que usar a sabedoria a fim de que o povo do reino de Matamba a aceitasse como líder de estado e assim pudesse está à frente de todas as decisões políticas e financeiras das terras desse lugar de África. De acordo com Agualusa (2015, p.49), "Ginga conseguira convencer os macotas a aceitaremna como rainha, ainda com forte oposição de muito deles, os quais preferiam ver no lugar dela um filho, ainda muito pequeno, de Ngola Mbandi". Essa passagem demonstra a pouca confiança dos Ambundus com a liderança feminina, a ponto de levantar a hipótese de uma criança chefiar um dos reinos mais importantes de Angola. 


\section{CONSIDERAÇÕES FINAIS}

No romance, A Rainha Ginga e de Como os Africanos inventaram há um narrador-personagem. Este narrador, muitas vezes, omite-se sobre a trajetória da rainha, para relatar a origem dele e os fatos que o levaram a ser padre. No entanto, é possível perceber a força e poder que ela exercia. Isso numa época em que poucas mulheres ousavam liderar exércitos. Por isso, a rainha Ginga é um caso especial na história e na literatura de angolana. Assim, muitos autores africanos e afro-brasileiros buscam nessa mulher fonte para recriar a história da escravidão.

A monarca do Ndongo tornou-se um modelo de resistência contra o colonialismo português. E nos anos de 1970, período pré-independência de Angola, ela volta na memória do povo, por meio do discurso literário. Os discursos literário e histórico trazem para os nossos dias, as lutas contra o imperialismo europeu em África. Os discursos literários, muito deles vindos de relatos orais, evidenciam a grandeza e sabedoria de Ginga Mbandi. Estes mesmos expõem o lado enigmático, lendário e mítico. Os discursos históricos elencam os feitos de Ginga contra os portugueses. Em alguns, teóricos, nota-se certo nível de estigmatização, principalmente entre os europeus. Muitos deles acusam-na de impiedosa, pervertida, revanchista. 
A nobre de Matamba e Ndongo não media esforços para alcançar êxito contra os conquistadores europeus. E para isso, Ginga utilizava como estratégia alianças contra os invasores. Ela decretava guerra para aqueles que lutassem ao lado dos portugueses. Por isso, ela também foi acusada de mandar decaptar o próprio tio, envenenar o irmão e apunhalar o filho de Ngola levando à morte deles. Dito dessa forma parece que Ginga é uma mulher cruel, revanchista. Porém, tais atos garantem a ela um longo reinado e domínio do território Matamba e Ndongo. Além de garantir êxito nos objetivos dela que eram a retomada dos territórios africanos, o fim da escravidão e do tráfico. Por esse, e outros motivos, cinco séculos depois a população angolana ainda a tem na memória.

Ao longo das leituras realizadas, acerca da heroína de Angola notou-se que ela foi responsável por mudanças significativas no curso da história desse país africano. A liderança dela evitou que muitos africanos passassem pela escravidão, face mais degradante da conquista europeia, junto com a expropriação da pátria de origem. Ela tornouse um exemplo de patriotismo, pois sem usar a força física impôs-se diante dos portugueses. Não cedeu aos desígnios dos europeus e, para tanto usava de estratagemas, os quais anulavam o poderio do exército luso. É importante ressaltar que Ginga também teve que lidar com desavenças internas 
com reinos vizinhos, os quais não se posicionavam contra os europeus e ainda forneciam escravos e cediam terras de África aos inimigos lusos.

Portanto, o legado que foi deixado por Ginga não pode ser esquecido, pois ela foi uma mulher aguerrida, combativa. E diante dos conflitos bélicos, entre os africanos e o povo luso, no centro do embate, está presente a figura lendária da rainha Ginga. E no romance de Agualusa, há empenho em mostrar como uma mulher africana lutou contra a escravidão.

Histórias de mulheres como a Rainha Ginga devem está presentes nas páginas da literatura. Isso porque, muitas mulheres são ocultadas do centro dos discursos, histórico e literário. D. Ana de Sousa ou Ginga Mbandi representa e exalta a participação feminina nas lutas políticas e na gestão de um território. Mesmo um território fragmentado e com diversas etnias, como Angola. Os feitos da rainha de Angola merecem ser disseminados, para homens e mulheres. 0 exemplo dela fortalece as reivindicações por igualdade de gênero, nos diversos setores sociais. Pois apesar de várias conquistas, as mulheres são parte, ainda, de um segmento social considerado inferior. 


\section{REFERÊNCIAS}

AGUALUSA, José Eduardo (2015). A Rainha Ginga. Rio de Janeiro: Foz. 236 p. CALEY, Cornélio (2014). "Período de Resistência contra o Colonialismo Português: o papel da rainha Ginga Mbandi, Ekuikui e outros". In:

MATA, Inocência (Orgs.) A Rainha Nzinga Mbandi: história, memória e mito. 2. ed. Lisboa: Edições Colibri. p.69-76.

CAVAZZI, Antonio (2013). Njinga a Rainha de Angola: A relação de Antonio Cavazzi de Montecuccolo. Lisboa: Escolar.

FONSECA, Mariana Bracks (2010). "Rainha nzinga mbandi, imbangalas e portugueses: as guerras nos kilombos de Angola no século XVII". Caderno de História. Uberlândia, 23(2), 391-414.

KWONONOKA. Américo (2014). "Njinga Mbandi, Fonte Inspiradora da Mulher Angola". In: MATA, Inocência (Orgs.) A Rainha Nzinga Mbandi: história, memória e mito. 2. ed. Lisboa: Edições Colibri. p.59-67. MARTINS, Carla (2015). "Arendt: uma perspectiva feminina do espaço público?" Lisboa: Livro de Actas do 4 SOPCOM. p.701-711.

MUNANGA, Kabengelê (1996). "Origem e Histórico do Kilombo em África”. Revista USP , São Paulo, 28(2) 56-63.

SADIQI, Fátima (2008). Estereótipos e mulheres na cultura marroquina. In: http://www.scielo.br/pdf/cpa/n30/a03n30.pdf Acesso em 04. Dez. de 2016.

PANTOJA, Selma (2014). "Revisitando a Rainha Nzinga Histórias e Mitos da História". In: . MATA, Inocência (Orgs.) A Rainha Nzinga Mbandi: história, memória e mito. 2. ed. Lisboa: Edições Colibri. p.115-145.

SILVA, Maria Aparecida Oliveira (2010). Sexualidade e Poder em Plutarco: o exemplo de Cleópatra. In: http://www.fazendogenero.ufsc.br/9/ resources/anais/1278343967_ARQUIVO_2010TextoFazendoGenero9.pdf Acesso em 07. Jan. de 2017.

SOUINDOULA, Simão (2014). "A Rainha Nzinga: uma figura lendária, patrimônio da humanidade". In:______. MATA, Inocência (Orgs.). A Rainha Nzinga Mbandi: história, memória e mito. 2. ed. Lisboa: Edições Colibri. 
SOUZA, Talita Tavares Batista Amaral de (2003). "Escravidão interna na África antes do tráfico negreiro". Vértice, 5(2). 21-36.

PINTO, Alberto Oliveira (2015). História de Angola: Pré-história ao início do século XXI. Lisboa: Mercado das Letras.

Algemira de Macêdo Mendes possui graduação em Licenciatura Plena em Letras pela Universidade Estadual do Piauí (1993), Mestrado em Teoria Literária pela Universidade Federal de Pernambuco (2002), Doutorado em Letras pela Pontifícia Universidade Católica do Rio Grande do Sul (2006) com estágio de doutorado sanduíche em Coimbra-PT (2005). Pós- doutora em Literaturas Africanas de Língua Portuguesa pela Universidade de Lisboa. Professora Associada da Universidade Estadual do Piauí, Universidade Estadual do Maranhão ,atuando na Graduação e no Mestrado em Letras . Coordena o Mestrado Acadêmico em Letras, o Núcleo de Estudos Literários Piauienses -NELIPI,NELG e é Membro do Comitê Institucional de Pesquisa da UESPI, Conselho Editorial das revistas Pesquisa em Foco (UEMA) e Letras em Revista (UESPI). Tem experiência na área de Letras, com ênfase em Literatura Feminina, História da Literatura, atuando principalmente nos seguintes temas: Literatura brasileira, Literatura piauiense, Literatura e ensino e Africanas de Língua Portuguesa

Maria do Desterro da Silva Oliveira é mestranda em Letras pela Universidade Estadual do Piauí. Possui graduação em Bacharelado em Biblioteconomia - Universidade Estadual do Piauí (2009), graduação em Letras - Português pela Universidade Federal do Piauí (2013). Especialista em Literatura, Estudos Culturais e outras linguagens. Tem experiência na área de Letras, com ênfase em Linguística e Literatura Brasileira, atuando principalmente nos seguintes temas: Linguagem, Literatura, Metodologia da Pesquisa e Ensino 